\title{
Effect of Some Fungicides against Early Blight of Tomato (Lycopersicon esculentum Mill.) Caused by Alternaria solani (Ell. \& Mart.) Jones and Grout and their Impact on Yield
}

\author{
R.K. Sharma*, D.R. Patel, D.R. Chaudhari, V. Kumar and M.M. Patel \\ Agricultural Research Station, Sardarkrushinagar Dantiwada Agricultural University \\ Ladol, Mehsana, Gujarat, India - 382840 \\ *Corresponding author
}

\begin{abstract}
A B S T R A C T
Keywords

Tomato, Early

Blight, Alternaria

solani, Fungicides

and Botanicals,

Carbendazim,

Mancozeb,

Azadirachta indica,

Percent Disease

Intensity,

management

Article Info

Accepted:

10 June 2018

Available Online:

10 July 2018

The efficacy of some fungicides like carbendazim $12 \%+$ mancozeb $63 \% \mathrm{WP}$, difenoconazole $25 \mathrm{EC}$, propiconazole $25 \mathrm{EC}$ along with commonly used fungicides viz., mancozeb $75 \mathrm{WP}$, propineb $70 \mathrm{WP}$, copper-oxy-chloride $50 \% \mathrm{WP}$ and one botanical Azadirachta indica (neem) leaf extract (20\%) were tested against early blight of tomato $c v$. Abhinav at Agricultural Research Station, Ladol, Gujarat. A variant with no application of fungicide was used as a control. All fungicide treatments reduce the disease intensity as compared to untreated check. The lowest percent disease intensity (PDI) was observed in carbendazim $12 \%$ + mancozeb $63 \%$ WP @ $0.2 \%$ (18.77) followed by difenoconazole 25 EC@ $0.025 \%$ (20.59) and propiconazole 25 EC @ $0.025 \%$ (21.52) treatments. Similarly, the highest yield of tomato fruits was recorded with carbendazim $12 \%+$ mancozeb $63 \%$ WP @ $0.2 \%$ (35257 kg/ha) followed by propiconazole 25 EC @ 0.025 $\%$ (32328 kg/ha) and difenoconazole 25 EC @ $0.025 \%$ (32202 kg/ha) when sprayed three times at an interval of 15 days starting from the initiation of the disease. The highest cost benefit ratio was obtained with treatment carbendazim $12 \%+$ mancozeb $63 \%$ WP

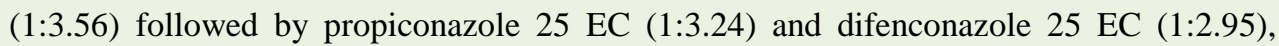
however, propineb $70 \mathrm{WP}(1: 2.60)$, mancozeb $75 \mathrm{WP}$ (1:2.59), copper-oxy-chlorode $50 \%$ WP (1:2.16) and neem leaf extract $20 \%(1: 2.06)$ were promising in obtaining higher returns over control.
\end{abstract}

\section{Introduction}

Tomato (Lycopersicon esculentum Mill.) is the second most important remunerable solanaceous vegetable crop after potato (Sahu et. al., 2013). It is native to South America and is widely cultivated in 140 countries of the world. In India, it has an annual production of
18732 thousand mt with 774 thousand ha area (Anonymous, 2017). Tomato ranks next to the potato crop and ranks first among the processing crops in the world acreage. Tomato is commonly consumed in our daily life and it is a good source of antioxidants (Borguini and Torres, 2009). Tomato contains $95.3 \%$ of water, $0.07 \%$ calcium and niacin, all of which 
have great importance in metabolic activities of humans. With high nutritional value, it provides a balance source of Vitamin A, C and $\mathrm{E}$ needed to maintain good human health (Olaniyi et al., 2010). Varied climatic adaptability and high nutritive value made the tomato cultivation more popular in the recent years. Tomato crop is vulnerable to infect by bacterial, viral, nematode and fungal diseases. Among the fungal diseases, Alternaria leaf blight of tomato caused by Alternaria solani (Ellis and Martin) Jones and Grout, is a soil inhabiting air-borne pathogen responsible for leaf blight, collar and fruit rot of tomato disseminated by fungal spores (Datar and Mayee, 1981). It is an important disease of tropical and sub-tropical areas. Distinctive bulls-eye pattern of leaf spots with concentric rings of spores surrounded by a halo of chlorotic leaf area are common. Leaves turn yellow and dry up when only a few spots are present (Gleason and Edmonds, 2006). The pathogen causes infection on leaves, stem, petiole, twig and fruits as well as leads to the defoliation, drying of twigs and premature fruit drop which ultimately reduce the yield 30 to $65 \%$ in various states (Basu, 1974; Datar and Mayee, 1981; Kamble et al., 2009; Saha and Das, 2013). The disease, if favoured by high temperature and humidity (crowded plantation, high rainfall and extended period of leaf wetness from dew) and plants are more susceptible to the blight infection during fruiting period (Momel and Pemezny, 2006). Fungicides and botanicals application can increase the genetic potential and yield reduction due to disease can be minimized (Patel and Choudhary, 2010; Chourasiya et al. 2013; Kumar et al., 2017). Preventive fungicides and botanicals inhibit the spore germination and penetration but pathogen can derive resistance against fungicide application so repeated application of fungicides at proper dose and interval of time is mandatory (Hossain and Hossain, 2009; Kumara et al., 2010). Application of fungicides and botanicals against early blight has been reported in India by various workers (Arunakumara et al., 2010; Dheeba et al., 2015). Unplanned and wide use of fungicides often leads to serious environmental problems besides affecting the health of users and consumers. So, it is necessary to minimize the use of chemicals for controlling disease. Present study was aimed to determine the efficacies of different doses of fungicides and botanical against Alternaria leaf blight of tomato under North Gujarat Agro-climatic condition as this disease causes enormous losses.

\section{Materials and Methods}

The experiment was conducted at Agricultural Research Station, S. D. Agricultural University, Ladol, Gujarat during the year 2014-15 to 2016-17 in rabi seasons using $c v$. abhinav for the management of early blight of tomato caused by Alternaria solani (Ell. \& Mart.) Jones and Grout. The soil of the experimental field was sandy loam. The experiment was laid out in a randomized block design with three replications. All recommended agronomic practices were followed. Thirty to thirty five days old seedlings raised in nursery were transplanted in the month of September at a distance of 90 $\mathrm{cm}$ X $60 \mathrm{~cm}$ spacing by using 10 gram seed with the gross area of $5.4 \mathrm{~m} \mathrm{X} 6.0 \mathrm{~m}=32.4$ $\mathrm{m}^{2}$. Efficacies of seven fungicides (including neem leaf extract@ $@ 20 \%$ conc.) with their prefixed concentrations (as per treatments) were compared with untreated control. Three sprays of each fungicide with their prefixed concentration were applied at an interval of 15 days after the initiation of the disease. The per cent disease intensity was recorded as per three consecutive sprays of fungicides at 7 and 15 days intervals. On the basis of symptoms (Figure 1 and 2) and microscopic studies, the fungus was identified as Alternaria solani, causative agent of early blight of tomato (Ellis 
and Martin, 1882) Jones and Grout, 1897. The observations on the intensity of early blight disease of tomato were recorded from 5 plants randomly selected from each plot using 0-5 scale as detailed in Table 1.

Percent Disease Intensity (PDI) was calculated by using the following formula given by Chestar, 1959 and Weeler, 1969.

PDI = $\begin{gathered}\text { Sum of all disease ratings } \\ \text { Po } 100\end{gathered}$

Total no. of observations (sample) X Maximal disease rating grade

Based on these observations, percent disease intensity (PDI) of early blight of tomato was recorded. The per cent disease intensity data was arcsine transformed before analysis of variance (ANOVA). Statistical analysis was done with using the standard procedure described by Gomez and Gomez (1986).

\section{Results and Discussion}

\section{Effect of fungicides on the disease intensity of early blight of tomato}

The data on PDI of early blight was recorded periodically at 7 and 15 days after consecutively spray of fungicides at 15 days interval. The data on disease intensity showed that all the fungicides tested reduce the disease intensity significantly as compared to untreated control. It is revealed from the data that there was significant difference in percent disease intensity during 2014-15, 2015-16, and 2016-17 and pooled also (Table 2). The minimum percent disease intensity was observed in $\mathrm{T}_{5}$ i.e. spraying of carbendazim 12 $\%+$ mancozeb $63 \%$ WP @ $0.2 \%$ and it was at par with treatments $\mathrm{T}_{7}$ i.e. spraying of propiconazole $25 \mathrm{EC} @ 0.025 \%, \mathrm{~T}_{6}$ i.e. spraying of difenoconazole 25 EC @ $0.025 \%$, $\mathrm{T}_{3}$ i.e. spraying of propineb $70 \mathrm{WP} @ 0.25 \%$ and $\mathrm{T}_{4}$ i.e. spraying of copper-oxy-chloride 50
\% WP @ $0.2 \%$ at 7 day after spraying. Whereas, the minimum per cent disease intensity at 15 days after spraying were recorded in $\mathrm{T}_{5}$ i.e. spraying of carbendazim 12 $\%+$ mancozeb $63 \%$ WP @ $0.2 \%$ and it was at par with $\mathrm{T}_{6}$ i.e. spraying of difenoconazole $25 \mathrm{EC} @ 0.025 \%$ and $\mathrm{T}_{7}$ i.e. spraying of propiconazole 25 EC @ $0.025 \%$ in the year 2014-15. In the year 2015-16, the minimum PDI was recorded in $\mathrm{T}_{5}$ i.e. spraying of carbendazim 12\%+mancozeb 63\%WP @ $0.2 \%$ and it was at par with the treatment $\mathrm{T}_{6}$ i.e. spraying of difenoconazole $25 \mathrm{EC}$ @ $0.025 \%$ at 7 days after spraying. Whereas, at 15 days after spraying the minimum PDI observed in the same treatment $\mathrm{T}_{5}$ i.e. spraying of carbendazim $12 \%+$ mancozeb 63 $\%$ WP @ $0.2 \%$. In the next year, the minimum PDI was recorded in the treatment $\mathrm{T}_{5}$ i.e. spraying of carbendazim $12 \%+$ mancozeb $63 \%$ WP @ $0.2 \%$ at 7 and 15 days after spraying and found it was significantly inferior over rest of the treatments during the year 2016-17. In pooled data, all the treatments except $T_{1}$ were at par and produced significantly lower percent disease intensity as compared to control. Thus, application of carbendazim $12 \%+$ mancozeb 63\% WP @ $0.2 \%$ found better for management of early blight in tomato. Later on, difenoconazole 25 EC @ $0.025 \%$ and propiconazole 25 EC @ $0.025 \%$ during the course of investigation (Table 2).

\section{Effect of fungicides on the yield of early blight of tomato}

Effect of different treatments on tomato yield was found significant during all the years and pooled also (Table 3). During the year 201415, spraying of carbendazim $12 \%+$ mancozeb 63 \% WP @ $0.2 \%$ recorded significantly higher yield and found superior over rest of the treatments. In 2015-16, treatment $\mathrm{T}_{5}$ i.e. spraying of carbendazim 12 $\%+$ mancozeb 63\%WP @ 0.2\% recorded 
significantly the maximum yield of tomato and it was at par with treatments $\mathrm{T}_{6}, \mathrm{~T}_{7}, \mathrm{~T}_{2}$ and $\mathrm{T}_{3}$. While during 2016-17, treatment $\mathrm{T}_{5}$ i.e. spraying of carbendazim $12 \%+$ mancozeb 63 $\%$ WP @ $0.2 \%$ recorded significantly higher yield than control and it was found at par with treatments $T_{7}, T_{6}, T_{2}, T_{4}$ and $T_{3}$. In pooled data, spraying of carbendazim $12 \%+$ mancozeb $63 \%$ WP @ $0.2 \%$ showed the maximum yield and statistically near to equal with treatments $T_{7}$ and $T_{6}$ but significantly superior over rest of the treatments. Higher yield under this treatments might be due to better control of blight by these combination fungicide formulations (Table 2). Thus, spraying of carbendazim $12 \%$ + mancozeb 63 $\%$ WP @ $0.2 \%$ found effective fungicide not only in terms of control of early blight but increase the yield also.

Table.1 intensity of early blight disease of tomato

\begin{tabular}{|c|l|l|}
\hline Disease Score & & Disease Intensity \\
\hline $\mathbf{0}$ & $:$ & Leaves free from infection. \\
\hline $\mathbf{1}$ & $:$ & Small irregular spots covering < 5\% leaf area. \\
\hline $\mathbf{2}$ & $:$ & Small irregular brown spots with concentric rings covering 5.1-10\% leaf area. \\
\hline $\mathbf{3}$ & $:$ & $\begin{array}{l}\text { Lesions enlarging, irregular brown with concentric rings covering 10.1-25\% leaf } \\
\text { area. }\end{array}$ \\
\hline $\mathbf{4}$ & $:$ & $\begin{array}{l}\text { Lesions coalease to form irregular and appears as a typical blight } \\
\text { symptom covering 25.1-50\% leaf area. }\end{array}$ \\
\hline $\mathbf{5}$ & $:$ & $\begin{array}{l}\text { Lesions coalease to form irregular and appears as a typical blight symptom } \\
\text { covering >50\% leaf area. }\end{array}$ \\
\hline
\end{tabular}

Table.4 Economics of different treatments of early blight of tomato

\begin{tabular}{|c|c|c|c|c|c|c|}
\hline $\begin{array}{l}\text { Sr. } \\
\text { No }\end{array}$ & Treatment details & $\begin{array}{l}\text { Yield } \\
\mathrm{Kg} / \mathrm{ha}\end{array}$ & $\begin{array}{c}\text { Gross } \\
\text { Realization } \\
\text { (Rs.) }\end{array}$ & $\begin{array}{l}\text { Cost } \\
\text { of } \\
\text { Inputs }\end{array}$ & $\begin{array}{c}\text { Net Realiz } \\
\text { ation } \\
\text { (Rs.) }\end{array}$ & IBCR \\
\hline 1 & neem leaf Extract @20\% concentration & 23083 & 207747 & 67963 & 139784 & $1: 2.06$ \\
\hline 2 & mancozeb 75 WP @0.2\% (2.7 gm / litre) & 27473 & 247257 & 68823 & 178434 & $1: 2.59$ \\
\hline 3 & propineb 70 WP @ $0.25 \%$ (3.5 gm / litre) & 28028 & 252252 & 70023 & 182229 & $1: 2.60$ \\
\hline 4 & $\begin{array}{l}\text { copper-oxy-chlorode } 50 \text { \% WP @ } 0.2 \% \text { (4 } \\
\text { gm / litre) }\end{array}$ & 25141 & 226269 & 71623 & 154646 & $1: 2.16$ \\
\hline 5 & $\begin{array}{l}\text { carbendazim } 12 \%+\text { mancozeb } 63 \% \text { WP @ } \\
0.2 \%(2.7 \mathrm{gm} / \text { litre })\end{array}$ & 35257 & 317313 & 69523 & 247790 & $1: 3.56$ \\
\hline 6 & $\begin{array}{l}\text { difenconazole 25 EC @ } 0.025 \text { \% (1 ml / } \\
\text { litre) }\end{array}$ & 32202 & 289818 & 73423 & 216395 & $1: 2.95$ \\
\hline 7 & $\begin{array}{l}\text { propiconazole } 25 \mathrm{EC} @ 0.025 \%(1 \mathrm{ml} / \\
\text { litre) }\end{array}$ & 32328 & 290952 & 68548 & 222404 & $1: 3.24$ \\
\hline 8 & untreated Control & 21238 & 191142 & 66423 & 124719 & $1: 1.88$ \\
\hline
\end{tabular}


Table.2 Effect of different treatments on Percent Disease Intensity of early blight of tomato

\begin{tabular}{|c|c|c|c|c|c|c|c|c|c|}
\hline \multirow{3}{*}{$\begin{array}{l}\text { Sr. } \\
\text { No. }\end{array}$} & \multirow[t]{3}{*}{ Treatments } & \multicolumn{8}{|c|}{ Per cent Disease Intensity (PDI) } \\
\hline & & \multicolumn{2}{|c|}{ 2014-15 } & \multicolumn{2}{|c|}{ 2015-16 } & \multicolumn{2}{|c|}{ 2016-17 } & \multicolumn{2}{|c|}{ Pooled } \\
\hline & & $7 \mathrm{DAS}$ & 15 DAS & 7 DAS & 15 DAS & 7 DAS & 15 DAS & 7 DAS & 15 DAS \\
\hline $\mathbf{T}_{1}$ & $\begin{array}{l}\text { neem leaf extract @ } 20 \% \\
\text { conc. }\end{array}$ & $\begin{array}{c}31.08 \\
(26.67)\end{array}$ & $\begin{array}{c}31.08 \\
(26.67)\end{array}$ & $\begin{array}{c}27.78 \\
(21.78)\end{array}$ & $\begin{array}{c}30.20 \\
(25.33)\end{array}$ & $\begin{array}{c}30.20 \\
(25.33)\end{array}$ & $\begin{array}{c}31.27 \\
(26.92)\end{array}$ & $\begin{array}{l}29.69 \\
(24.59)\end{array}$ & $\begin{array}{c}30.85 \\
(26.31)\end{array}$ \\
\hline $\mathbf{T}_{2}$ & $\begin{array}{l}\text { mancozeb } 75 \text { WP @ } 0.2 \% \\
\text { ( } 2.7 \mathrm{gm} / \text { litre) }\end{array}$ & $\begin{array}{c}23.29 \\
(16.00)\end{array}$ & \begin{tabular}{|c|}
22.48 \\
$(14.67)$
\end{tabular} & $\begin{array}{c}25.46 \\
(18.51)\end{array}$ & $\begin{array}{c}25.89 \\
(19.11)\end{array}$ & $\begin{array}{c}24.92 \\
(17.77)\end{array}$ & $\begin{array}{c}25.80 \\
(18.96)\end{array}$ & $\begin{array}{l}24.55 \\
(17.43)\end{array}$ & $\begin{array}{c}24.72 \\
(17.58)\end{array}$ \\
\hline $\mathbf{T}_{3}$ & $\begin{array}{l}\text { propineb } 70 \text { WP @ } 0.25 \% \\
\text { (3.5 gm / litre) }\end{array}$ & $\begin{array}{c}20.27 \\
(12.00)\end{array}$ & $\begin{array}{c}22.48 \\
(14.67)\end{array}$ & $\begin{array}{c}26.63 \\
(20.14)\end{array}$ & $\begin{array}{c}27.27 \\
(21.03)\end{array}$ & $\begin{array}{c}26.85 \\
(20.44)\end{array}$ & $\begin{array}{c}27.69 \\
(21.62)\end{array}$ & $\begin{array}{c}24.58 \\
(17.53)\end{array}$ & $\begin{array}{c}25.81 \\
(19.11)\end{array}$ \\
\hline $\mathbf{T}_{4}$ & $\begin{array}{l}\text { copper-oxy-chloride } 50 \% \\
\text { WP @ } 0.2 \% \text { (4 gm / litre) }\end{array}$ & $\begin{array}{c}20.27 \\
(12.00)\end{array}$ & $\begin{array}{l}17.71 \\
(9.33)\end{array}$ & $\begin{array}{c}25.78 \\
(18.96)\end{array}$ & $\begin{array}{c}26.74 \\
(20.29)\end{array}$ & $\begin{array}{c}28.62 \\
(22.96)\end{array}$ & $\begin{array}{c}28.92 \\
(23.40)\end{array}$ & $\begin{array}{c}24.89 \\
(17.97)\end{array}$ & \\
\hline $\mathbf{T}_{\mathbf{5}}$ & $\begin{array}{l}\text { carbendazim } 12 \%+ \\
\text { mancozeb } 63 \% \text { WP @ } 0.2 \\
\%(2.7 \mathrm{gm} / \text { litre })\end{array}$ & $\begin{array}{c}16.08 \\
(08.00)\end{array}$ & $\begin{array}{l}13.17 \\
(5.33)\end{array}$ & $\begin{array}{c}21.38 \\
(13.33)\end{array}$ & $\begin{array}{c}21.61 \\
(13.63)\end{array}$ & $\begin{array}{c}20.77 \\
(12.59)\end{array}$ & $\begin{array}{c}21.53 \\
(13.48)\end{array}$ & $\begin{array}{c}19.41 \\
(11.31)\end{array}$ & $\begin{array}{c}18.77 \\
(10.81)\end{array}$ \\
\hline$T_{6}$ & $\begin{array}{l}\text { difenoconazole 25 EC @ } \\
0.025 \% \text { (1 ml / litre) }\end{array}$ & $\begin{array}{l}17.71 \\
(9.33)\end{array}$ & $\begin{array}{l}14.80 \\
(6.67)\end{array}$ & $\begin{aligned} 22 . & \\
(14.2 & \end{aligned}$ & $\begin{array}{c}23.65 \\
(16.14)\end{array}$ & $\begin{array}{r}23.0 \\
(15.4\end{array}$ & $\begin{array}{c}23.32 \\
(15.70)\end{array}$ & $\begin{array}{c}20.97 \\
(12.98)\end{array}$ & $\begin{array}{c}20.59 \\
(12.84)\end{array}$ \\
\hline $\mathbf{T}_{7}$ & $\begin{array}{l}\text { propiconazole 25 EC @ } \\
0.025 \%(1 \mathrm{ml} / \text { litre })\end{array}$ & $\begin{array}{l}16.08 \\
(8.00)\end{array}$ & $\begin{array}{l}16.43 \\
(6.66)\end{array}$ & $\begin{array}{r}23.37 \\
(15.85)\end{array}$ & $\begin{array}{c}24.01 \\
(16.59)\end{array}$ & $\begin{array}{c}23.89 \\
(16.44)\end{array}$ & $\begin{array}{c}24.13 \\
(16.74)\end{array}$ & $\begin{array}{c}21.11 \\
(13.43)\end{array}$ & $\begin{array}{c}21.52 \\
(13.33)\end{array}$ \\
\hline $\mathbf{T}_{8}$ & untreated Control & $\begin{array}{c}46.92 \\
(53.33)\end{array}$ & $\begin{array}{c}49.22 \\
(57.33)\end{array}$ & $\begin{array}{c}35.95 \\
(34.51)\end{array}$ & $\begin{array}{c}37.73 \\
(37.48)\end{array}$ & $\begin{array}{c}35.60 \\
(33.92)\end{array}$ & $\begin{array}{c}36.31 \\
(35.10)\end{array}$ & $\begin{array}{c}39.49 \\
(40.59)\end{array}$ & $\begin{array}{c}41.08 \\
(43.30)\end{array}$ \\
\hline & S.Em & 1.77 & 1.17 & 0.61 & 0.34 & 0.50 & 0.44 & 2.14 & 2.46 \\
\hline & C.D $(\mathrm{P}=0.05)$ at $5 \%$ & & & 1.8 & 1. & & 1.3 & 6.50 & 7.46 \\
\hline & C.V\% & 12.77 & & 4.05 & 2.12 & 3.23 & 2.80 & 7.56 & 5.0 \\
\hline & Y X T & & & & & & & $\mathrm{S}$ & $\mathrm{S}$ \\
\hline
\end{tabular}

* Figures in the parenthesis are original values.

PDI $=$ Per cent Disease Intensity, DAS $=$ Day after spraying

Table.3 Effect of different treatments on yield of early blight of tomato

\begin{tabular}{|c|c|c|c|c|c|}
\hline \multirow{2}{*}{$\begin{array}{l}\text { Sr. } \\
\text { No. }\end{array}$} & \multirow[t]{2}{*}{ Treatments } & \multicolumn{4}{|c|}{ Tomato Yield, Kg/ha } \\
\hline & & 2014-15 & 2015-16 & 2016-17 & Pooled \\
\hline $\mathbf{T}_{1}$ & neem leaf extract @ 20\% conc. & 18961 & 23611 & 26677 & 23083 \\
\hline $\mathbf{T}_{2}$ & mancozeb 75 WP @ 0.2\% (2.7 gm / litre) & 25813 & 25977 & 30628 & 27473 \\
\hline $\mathbf{T}_{3}$ & propineb 70 WP @ $0.25 \%$ (3.5 gm / litre) & 29465 & 25298 & 29321 & 28028 \\
\hline $\mathbf{T}_{4}$ & copper-oxy-chloride 50\%WP @ $0.2 \%$ (4 gm / litre) & 22150 & 24352 & 28920 & 25140 \\
\hline $\mathbf{T}_{5}$ & carbendazim $12 \%+$ mancozeb $63 \%$ WP @ $0.2 \%$ (2.7 gm / litre $)$ & 41235 & 30010 & 34527 & 35257 \\
\hline$T_{6}$ & difenoconazole 25 EC @ 0.025\% (1 ml / litre $)$ & 33416 & 28992 & 34198 & 32202 \\
\hline $\mathbf{T}_{7}$ & propiconazole 25 EC @ $0.025 \%$ (1 ml / litre) & 33930 & 28796 & 34260 & 32328 \\
\hline $\mathbf{T}_{8}$ & untreated Control & 16142 & 22479 & 25092 & 21238 \\
\hline & S.Em & 1036 & 1583 & 1869 & 1861 \\
\hline & C.D at $5 \%(\mathrm{P}=0.05)$ & 3142 & 4798 & 5665 & 5649 \\
\hline & C.V\% & 6.50 & 10.46 & 10.62 & 9.46 \\
\hline & Y X T & & & & 4384 \\
\hline
\end{tabular}




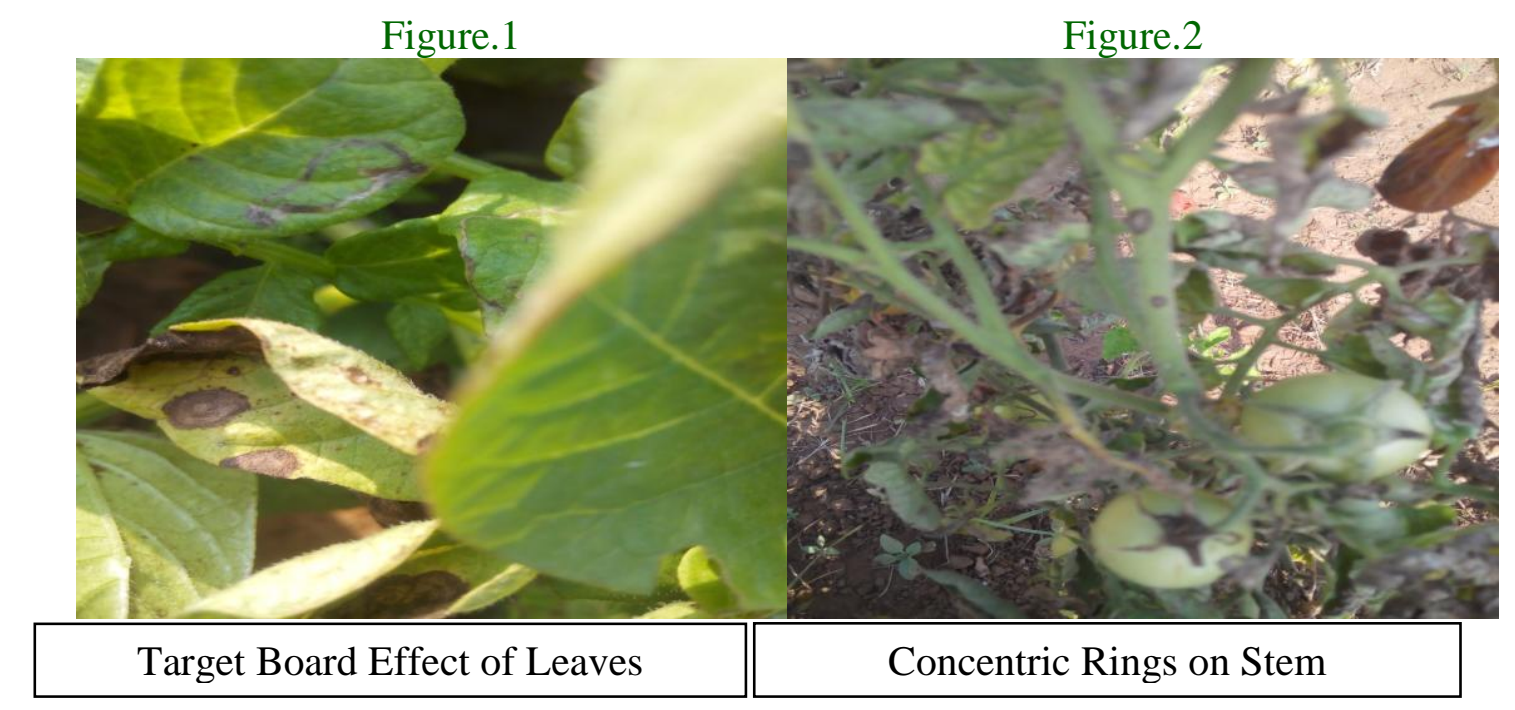

\section{Economics of the treatments of early blight of tomato}

In this experiment, the maximum net realization of Rs. 247790 with IBCR 1:3.56 was obtained in the treatment carbendazim $12 \%+$ mancozeb $63 \%$ WP @ $0.2 \%$ concentration $\left(\mathrm{T}_{5}\right)$ followed by propiconazole 25 EC @ $0.025 \%$ concentration $\left(\mathrm{T}_{7}\right)$ and difenoconazole 25 EC @ $0.025 \%$ concentration $\left(\mathrm{T}_{6}\right)$ with net realization 222404, IBCR 1:3.24 and 216395, BCR 1:2.95, respectively (Table 4).

In the present study, the minimum disease intensity of early blight and maximum yield was found when carbendazim $12 \%+$ mancozeb $63 \%$ WP @ $0.2 \%$ was used as foliar spray. The probable reason for such finding may be that, carbendazim + mancozeb would have affected the spore germination and mycelial development, which may have resulted in the inhibition of disease producing activity of pathogen in the plant and induced resistance in plant. This resulted in better overall growth and good health of tomato plants. This may be the reason for minimum disease intensity and maximum yield as compared to other treatments. Similar trends were reported by (Prasad and Nayak, 2003; Hooda et al., 2008). They also reported that carbendazim and mancozeb was the most effective fungicides recorded minimum disease intensity against early blight of tomato. This was also supported by the findings of (Tiwari et al., 2004; Yadav and Dabbas, 2012) against early blight of Potato. carbendazim and mancozeb @ 0.2 was the most effective fungicides in managing the disease intensity of early blight on tomato caused by Alternaria solani. This fungicide also gave higher yield $(\mathrm{kg} / \mathrm{ha})$ and was the most economical with IBCR 1:3.56.

\section{References}

Anonymous 2017. Horticultural Statistics at a Glance, Ministry of Agriculture and Farmers Welfare, Govt. of India, 2017 pp.140-151.

Arunakumara, K. T., Kulkarni, M. S., Thammaiah, N and Hegde, Y. 2010. Fungicidal management of early blight of tomato. Indian Phytopathol. 63: 96-97.

Basu, P. K. 1974. Measuring early blight, its progress and influence on fruit losses in nine tomato cultivars. Can. Plant Dis. Surv. 54: 45-51.

Borguini, R. and Torres, E. 2009. Tomatoes and tomato products as dietary sources of antioxidants. Food Rev. Int. 25: 313-325.

Chester, K. S. 1959. How sick is the plant? In "Plant Pathology an Advance Traits" (Eds J. G. Horsfall and A. E. Diamond) Vol.1, Academic Press, New York. pp. 199-242.

Chourasiya, P. K., Lal, A. A. and Simon, S. 2013. Effect of certain fungicides and botanicals 
against early blight of tomato caused by Alternaria solani (Ellis and Martin) under allahabad uttar pradesh, India conditions. Int. J. Agril. Sci. and Res. 3(3): 151-156.

Datar, V. V. and Mayee, C. D. 1981. Assesment of loss in tomato yield due to early blight. Indian Phytopathol. 34: 191-195.

Dheeba, B., Niranjana, R., Sampathkumar, P., Kannan, K. and Kannan, M. 2015. Efficacy of neem (Azadirachta indica) and tulsi (Ocimum sanctum) leaf extracts against early blight of tomato. Proceedings of National Academy of Sciences in India, Section B, Biological Sciences. 85: 327-336.

Ellis, J. B. and Martin, G. B. 1882. Macrosporium solani E\&M. Amer. Nat. 16: 1003.

Gleason, M. L. and Edmonds, B. A. 2006. Tomato diseases and disorders. 1266-1277.

Gomez, K. A. and Gomez, A. A. 1986. Statistical procedures for agriculture research. 2nd edition, John Wiley and Sons. pp. 680.

Hooda, K. S., Bhatt, U. C., Joshi, D. and Gupta, H. S. 2008. Biocontrol agents vis-a-vis fungicides in managing various diseases of tomato (Lycopersicon esculentum Mill.) in hills of Uttarakhand. Indian Phytopathol. 61(3): 331-336.

Hossain, M. S. and Hossain M. M. 2009. Efficacy of foliar fungicides in controlling early blight of tomato. Bangladesh J. Plant Pathol. 25: 51-55.

Jones, L. R. and Grout, A. J. 1897. Notes on two species of Alternaira. Bull. Torrey Bot. Soc. 24: 254-258.

Kamble, S. B., Sankeshwari, S. B. and Arekar, J. S. 2009. Survey on early blight of tomato caused by Alternaria solani. Int. J. Agril. Sci. 5: 317-319.

Kumar, V., Singh, G. and Tyagi, A. 2017. Evaluation of different fungicides against alternaria leaf blight of tomato (Alternaria solani). Int. J. Curr. Microbiol. App. Sci. 6(5): 2343-2350.

Kumara, A., Kulkarni, K. T., Thammaiah, M. S. and Hegde, N. 2010. Fungicidal management of early blight of tomato. Indian Phytopathol. 63 (1): 96-97.

Momel, T.M., and Pemezny, K.L. 2006. Florida plant disease management guide: Tomato. Florida Cooperation Extensive Service, Institute of Food and Agriculture Sciences. $\quad 134 . \quad$ NHB. 2015. http://nhb.gov.in

Olaniyi, J. O., Akanbi, W. B., Adejumo, T. A. and Akande, O. G. 2010. Growth, fruit yield and nutritional quality of tomato varieties. Afr J Food Sci, 4: 398-402.

Patel, R. L. and Chaudhary, R. F. 2010. Management of Alternaria solani causing early blight of tomato with fungicides. $J$. Plant Dis. Sci. 5: 65-67.

Prasad, Y. and Naik, M. K. 2003. Evaluation of genotypes, fungicides and plant extracts against early blight of tomato caused by Alternaria solani. Indian J. Plant Prot. 31(2): 49-53.

Saha, P. and Das, S. 2013. Assesment of losses due to early blight of (Alternaira solani Ell. And Mart.) and influence of weather factors on disease development in tomato. J. Agrometeriol. 15: 82-85.

Sahu, D. K., Khare, C. P., Singh, H. K., and Thakur, M. P. 2013. Evaluation of newer fungicide for management of early blight of tomato in Chhattisgarh. The Bioscan. 8(4): 1255-1259.

Tiwari, R. K. S., Rajput, M. L. and Singh, A. 2004. Effect of sowing dates and spray schedule of mancozeb on early blight Alternaria solani of potato. Indian J. Plant Prot. 32 (2): 61-64.

Weeler, B E. J. 1969. An Introduction to Plant Disease. John Willey and Sons Limited, London. pp 301.

Yadav, O. P. and Dabbas, M. R. 2012. Efficacy of fungicides in the management of early blight of tomato (Alternaria solani). Int. J. Plant Prot. 5(2): 413-416.

\section{How to cite this article:}

Sharma, R.K., D.R. Patel, D.R. Chaudhari, V. Kumar and Patel, M.M. 2018. Effect of Some Fungicides against Early Blight of Tomato (Lycopersicon esculentum Mill.) Caused by Alternaria solani (Ell. \& Mart.) Jones and Grout and Their Impact on Yield. Int.J.Curr.Microbiol.App.Sci. 7(07): 1395-1401. doi: https://doi.org/10.20546/ijcmas.2018.707.166 